The Sea in the Greek Imagination 



\title{
THE SEA \\ IN THE GREEK \\ IMAGINATION
}

Marie-Claire Beaulieu

\author{
$\overline{\text { PENN }}$ \\ UNIVERSITY OF PENNSYLVANIA PRESS \\ PHILADELPHIA
}


Copyright (C) 2016 University of Pennsylvania Press

All rights reserved. Except for brief quotations used for purposes of review or scholarly citation, none of this book may be reproduced in any form by any means without written permission from the publisher.

$$
\begin{gathered}
\text { Published by } \\
\text { University of Pennsylvania Press } \\
\text { Philadelphia, Pennsylvania I9I04-4II2 } \\
\text { www.upenn.edu/pennpress }
\end{gathered}
$$

Printed in the United States of America on acid-free paper

$$
\text { I } 3579 \text { IO } 8642
$$

Library of Congress Cataloging-in-Publication Data

Beaulieu, Marie-Claire, 1979-

The sea in the Greek imagination / Marie-Claire Beaulieu.

pages $\mathrm{cm}$

Includes bibliographical references and index.

ISBN 978-0-8I22-4765-7

I. Ocean-Religious aspects. 2. Ocean-Mythology.

3. Mythology, Greek. 4. Liminality. 5. Life. 6. Death.

I. Title.

$\mathrm{BL}_{795 . \mathrm{O}_{34} \mathrm{~B} 432 \mathrm{OI} 6}$

292.2 '12-dc23 
$\grave{A}$ mes parents 
